\title{
The Correlation between Age, Years of Service, and Working Postures and the Complaints of Musculoskeletal Disorders
}

\section{Hubungan Usia, Masa Kerja dan Postur Kerja dengan Keluhan Musculoskeletal Disorders}

\author{
Buntari Asmaning Putri \\ The Indonesian Occupational Safety and Health Association, East Java Province \\ Jalan Dukuh Menanggal No.122, Dukuh Menanggal, Gayungan \\ Surabaya, East Java Indonesia 60234
}

\begin{abstract}
Introduction: Musculoskeletal Disorders (MSDs) is one of the health problems caused by the used equipment or performed activity while working. The workers in the packaging section of the iron and steel industry who do the packaging process manually are exposed to the risk of experiencing MSDs due to the working attitudes and nonergonomic postures. This study aims to identify the correlation between ages, years of service, as well as working postures and the complaints of MSDs experienced by the workers of the packaging section of iron and steel industry in Sidoarjo. Methods: This study applied a cross-sectional design. The research population was all workers in the packaging section of an iron and steel industry in Sidoarjo, reaching 27 people. The research samples are the total population of the workers in the packaging section of an iron and steel industry in Sidoarjo. The risk assessment of MSDs was carried out by using the Rapid Entire Body Assessment (REBA) method, while the risk complaints were measured by using the Nordic Body Map (NBM) questionnaire. The data were tested by using Chi-Square. Results: The results revealed that there were moderate correlations between the age and the MSDs complaints (phi coefficient $=0.335$ ), between the years of service and the MSDs complaints (phi coefficient $=0.433$ ), and between the working postures and MSDs complaints (phi coefficient=0.401). Conclusion: The moderate-level of correlation still affected the occurrence of MSDs complaints.
\end{abstract}

Keywords: ages, years of service, working postures, musculoskeletal disorders complaints

\begin{abstract}
ABSTRAK
Pendahuluan: Musculoskeletal Disorders (MSDs) merupakan salah satu gangguan kesehatan yang dapat diakibatkan dari alat yang digunakan dan aktivitas yang dilakukan selama melakukan pekerjaan. Pekerja bagian pengemasan pada industri besi dan baja yang melakukan proses pengemasan dengan cara manual mempunyai risiko mengalami keluhan musculoskeletal disorders dikarenakan sikap dan postur kerja yang tidak ergonomis. Penelitian ini bertujuan untuk mengidentifikasi hubungan antara usia kerja, masa kerja dan postur kerja dengan keluhan musculoskeletal disorders pada pekerja bagian pengemasan industri besi dan baja di Sidoarjo. Metode: penelitian ini menggunakan desain penelitian crossectional. Populasi yang diambil adalah seluruh pekerja bagian pengemasan industri besi dan baja di Sidoarjo sejumlah 27 orang. Sampel dalam penelitian ini merupakan total populasi pekerja di bagian pengemasan industri besi dan baja di Sidoarjo. Penilaian risiko musculoskeletal disorders dilakukan menggunakan metode Rapid Entire Body Assesment (REBA), sedangkan tingkat risiko keluhan musculoskeletal disorders dinilai menggunakan kuesioner Nordic Body Map (NBM). Data diuji menggunakan uji Chi-Square. Hasil: Hasil penelitian diperoleh bahwa terdapat hubungan yang sedang antara usia dengan keluhan MSDs (koefisien phi=0,335) dan masa kerja dengan keluhan MSDs (koefisien phi=0,433) dan postur kerja dengan keluhan MSDs (koefisien phi =0,401). Simpulan: Tingkat korelasi yang sedang tetap mempunyai efek terhadap timbulnya keluhan MSDs.
\end{abstract}

Kata kunci: keluhan musculoskeletal disorders, masa kerja, postur kerja, usia,

Corresponding Author:

Buntari Asmaning Putri

Email: buntari.putri@gmail.com

C2019 IJOSH All right reserved. Open access under CC BY NC-SA license doi: 10.20473/ijosh.v8i2.2019. 187-196

Received October 19, 2017, received in revised form March 15, 2019, Accepted August 05, 2019, Published: August 2019 


\section{INTRODUCTION}

Workforces are the main components to increase industry productivity. The implementation of Occupational Safety and Health (hereafter, OSH) programs in an industry are essential to realize the optimal work productivity and to protect the workers from the occupational risks that are alarming for their health and safety. Various occupational risks include the emergence of occupational illnesses and occupational accidents that can result in disabilities and death. Those risks can be prevented by optimizing the implementation of $\mathrm{OSH}$ in the working environment (Suma'mur, 2009).

The research conducted by Saputra, Naiem and Saleh (2013) discovered that $70 \%$ of their respondents complained about joint muscle pain after work. $92 \%$ of the respondents with joint muscle complaints had a sitting attitude that violates the ergonomic principles. As many as $84 \%$ of the respondents who experienced the complaints of joint muscles were discovered working in the working stations that were not in line with the ergonomic principles. The respondents who suffered from the complaints of joint muscles in the research aged $\geq 35$ years old, $(82.35 \%)$. Meanwhile, $78.6 \%$ of female respondents and $66.7 \%$ male respondents complained about joint muscle illness.

The respondents' age is directly proportional to the workers' physical capacity to a certain extent. The optimum physical ability occurs at the age of 25 years old. At the ages of 50-60 years old, there is a decrease in muscle strength by $25 \%$ and a decrease of sensorymotoric ability by $60 \%$. The physical ability of someone whose age is above 60 years old only reaches approximately $25 \%$ of the ability of someone ages below 60 years old (Tarwaka, Bakri and Sudiajeng, 2004).

The complaint of Musculoskeletal Disorders (hereafter, MSDs) is a complaint on the skeletal muscles, ranging from mild pain to severe pain. The muscles that receive repetitive static load for a long time can result in complaints such as joint, tendon, and ligaments fractures. The complaints and the fractures are commonly known as MSDs or injury to skeletal muscles (Tarwaka, Bakri and Sudiajeng, 2004).

The complaints of MSDs is one of the health problems caused by a job that ignores ergonomic principles. The report from the Bureau of Labour Statistics (BLS) affirmed that, in 1982, the compensation costs incurred by almost $20 \%$ of all occupational illnesses and $25 \%$ of the complaints came from back pains. MSDs are the result of non-ergonomic and long-working in a certain posture. MSDs are pathological conditions that influence the normal function of fine tissues in the MSD system that includes the nervous system, tendons, muscles, and supporting structures, such as discus invertebral (Woolf and Pfleger, 2003).

Working postures are the body postures or positions when working, from the tip of the hair to the tip of the toe. The body posture when working is the body position when working that does not cause changes in body angles (Ide, 2007).

The iron and steel industry in Sidoarjo is one of the iron and steel industries in Indonesia. The production process at the iron and steel industry has been complemented by sophisticated technologies to produce nails and wire for building materials. One of the work problems found in the production process is the ergonomic problems. These problems occur in the iron and steel industry in Sidoarjo more at the packaging process of the wires, wherein this process, the workers complete the packaging process manually. The workers cut the wires and tie them all together.

The workers of the iron and steel industry in Sidoarjo are the permanent workers whose salary is paid monthly. The workers perform the working activity by continuously standing and often bowing during the working hours in the production process. The break time of the workers is specifically regulated. The workers take a break for 30 minutes in the afternoon from a total of eight working hours, which starts from 8.00 a.m. to 4.00 p.m. There are occupational 
factors that can affect the work productivity, such as years of service, working hours, and working attitudes of the workers.

The ergonomic problems in the iron and steel industry in Sidoarjo, if related to the complaints of MSDs, can be resulting in the injury to the skeletal muscles. Thus, according to the brief explanation beforehand, the authors are eager to conduct a study on several factors that are related to the complaints of MSDs at the packaging section of the iron and steel industry in Sidoarjo.

One of the products of the iron and steel industry in Sidoarjo is the cut wires that are used as building construction materials, namely iron bone, as the basic material for casting. The complaints of MSDs of the production process workers of the iron and steel industry in Sidoarjo partly occur in the activities performed manually. Most of the workers complete their works in a standing position and even bowing. Standing and bowing for a long time can lead to saturation and fatigue. If the static condition is maintained, it will cause complaints to the MSDs system. Moreover, there are several factors that are likely to increase the risk of MSDs, for instance, excessive energy, repetition, and working periods (Tarwaka, Bakri and Sudiajeng, 2004).

This study aims to analyze the correlation between the characteristics and the working postures and the complaints of MSDs of the packaging section workers of the iron and steel industry in Sidoarjo.

\section{METHODS}

This study applied the cross-sectional design. This study was carried out by doing a one-time observation to both the dependent variables and the independent variables in a certain period of time. In term of location, this study is considered as a field study, while in terms of the objectives, this study is an observational descriptive study, in which the aims are to provide an objective description of a situation (Notoatmodjo, 2005).
The population of this study was all the workers of the packaging section of the iron and steel industry in Sidoarjo, amounting to 27 people. The whole population acted as the research samples. This study was carried out in an iron and steel industry in Kedungturi Village, Taman, Sidoarjo.

The dependent variables of this study were the age, years of service, and the working postures. Age is the accumulation of the respondents' life, calculated from birth until the time this study was conducted, with the assessment categories as follows: age of $<35$ years old; age of $\geq 35$ years old.

The years of service is the length of time the respondents work from the beginning until the time this study was conducted. The assessment categories are as follows: < 1 year; 1-5 years, and $>$ five years.

Working posture is the posture during work that poses the risk of MSDs. The risk assessment of the MSDs was carried out by applying the REBA method. The REBA method (Rapid Entire Body Assessment) is an instrument to analyze the sensitive working postures, including a sudden change of a posture as a result of unexpected handlings (Tarwaka, Bakri and Sudiajeng, 2004). The implementation of this method was aimed to prevent the risk of injuries related to positions, especially in the skeletal muscles. Due to that reason, this method was beneficial for risk prevention that also serves as a warning if improper working conditions occur in the workplace.

The REBA method is a method in evaluating risks, such as the risks in the skeletal muscle system. The REBA method divides the body segments, codes them, and evaluates all parts of the body (upper limbs and body, neck, and legs). The obtained final results were used to observe and determine the risk level of injuries by defining the required corrective actions and to be the basis for interventions to perform an improvement.

The body segments were divided into two groups. Group A consisted of the body, neck, and legs. Group B consisted of the upper limbs, such 
as upper arms, forearms, and wrists. After the grouping, the scores of each group were obtained. The score of Group A was obtained from the modified score based on the force. The score of Group B was based on container handling. The scores of Group A and B were then put into Table $\mathrm{C}$ to obtain the score $\mathrm{C}$. The modification of score $\mathrm{C}$ was based on the type of muscle activities which was then continued to obtain the final score. The assessment: An examination of the levels of action, risk, and urgency of corrective actions based on the final score obtained were categorized as follows: Very low $=$ score of 1 , action score $=0$, no action required; low $=$ score of 2-3, action score $=1$, actions may be required; moderate $=$ score of 4-7, action score $=2$, actions are required; High $=$ score of $8-10$, action score $=$ 3 , require immediate actions; very high $=$ score of $11-15$, action score $=4$, requires actions as soon as possible.

The dependent variable in this study was the complaints on MSDs. The complaints of MSDs is a complaint felt in the skeletal muscles of the body, whether it is before, during, or after work. The assessment of the complaints on MSDs was carried out by using the Nordic Body Map (hereafter, NBM) questionnaire. NBM was suitable to identify the parts of the muscle that suffer from the complaints. The levels of complaints on the pain are categorized as follows; $0=$ no pain felt; $1=$ a slight complaint or pain in the muscle but not disturbing the work with a score; 2 = a complaint or pain in the muscles and has interfered with the work, but the pain is gone after rest; $3=$ complaint of severe pain in the muscles and the pain still lingers even after long rest and in need for a painkiller

The assessment was completed based on the total scores that were divided into the following categories: Low $(28-49)=$ no corrective action is required; Moderate $(50-70)=$ corrective action may be required in the future; High (71-91) $=$ corrective action needs to be carried out as soon as possible; Very high (92$112)=$ comprehensive action needs to be carried out as soon as possible.
The time of complaints of MSDs is the time when the pain occurs and felt by the respondents, with the assessment categories as follows: Before work; During work; and After work.

The data processing was completed by applying univariate analysis, whose aim was to identify the correlation between the independent and dependent variables by implementing the cross-tabulation. The correlation strength determination between variables was completed by using Chi-square by examining the phi coefficient.

\section{RESULTS}

The iron and steel industry in Sidoarjo is a company emerging in the field of iron and steel industry. In addition to implementing the Environmental Management and Monitoring Plan $(R K L-R P L)$ that has been approved for the implementation of environmental management, the production process of the iron and steel industry in Sidoarjo also carries out the product and production process certification to protect the products and the workers involved in the production process as an early prevention of the impacts to the environment and occupational safety and health.

The iron and steel industry in Sidoarjo has implemented the ISO 9001:2008 of the quality management system to support the business activity with the orientation of the domestic and international markets. The quality system has been certified with the certificate number: ISO 9001:2008 (Approval Certificate No. 935895 by LRQA-Lloyd's Register). The recognition of the quality of the production process is expected to achieve the targets of zero accident, zero breakdowns, zero waste, and zero inventory. Other than that, the company's goals, which are the increase of the product quality, productivity, operational efficiency of the production, environmental pollution control, and the increase of occupational safety and health can all be achieved through the program. 
The age referred to in this study is the period of time calculated from birth to the time when the study was conducted. The ages of the workers were divided into two groups, i.e., the group of $<35$ years old; and the group of $\geq 35$ years old.

Table 1. Respondent Distribution Based on the Age Group in 2016

\begin{tabular}{ccc}
\hline Age (years old) & Frequency (n) & Percentage (\%) \\
\hline$<35$ & 10 & 37 \\
$\geq 35$ & 17 & 63 \\
\hline Total & 27 & 100 \\
\hline
\end{tabular}

Table 1 displayed that the majority of the workers of the packaging section belonged to the age group of $\geq 35$ years old as many as 17 people $(63 \%)$.

The years of service of the respondents were divided into three groups, namely the years of service of $<1$ year, years of service of 1-5 years, and years of service of $>5$ years. According to the calculation, the results are presented in Table 2 .

Table 2 showed that the respondents who worked for less than 8 hours in a day were as many as 25 people $(92.6 \%)$.

Table 2. The Distribution of the Respondents Based on the Years of Service in the Packaging Section of the Iron and Steel Industry in 2016

\begin{tabular}{lcc}
\hline Years of Service & Frequency $(\mathbf{n})$ & Percentage $(\boldsymbol{\%})$ \\
\hline$<$ 1year & 4 & 14.8 \\
$1-5$ years & 23 & 85.2 \\
\hline Total & 27 & 100 \\
\hline
\end{tabular}

The assessment on the workers' working postures was carried out by implementing the REBA method. The implementation of this method aimed to discover which positions of the limbs that can cause the emergence of the risks in the musculoskeletal disorders system. The final results obtained were used to discern and determine the level of risk injuries by establishing the levels of needed corrective actions as the basis of the interventions so that the improvements can be carried out immediately.

Table 3. Respondent Distribution Based on the Working Postures in 2016

\begin{tabular}{lcc}
\hline $\begin{array}{l}\text { Working Postures } \\
\text { Assessment }\end{array}$ & $\begin{array}{c}\text { Frequency } \\
(\mathbf{n})\end{array}$ & $\begin{array}{c}\text { Percentage } \\
(\mathbf{\%})\end{array}$ \\
\hline Low & 7 & 25.9 \\
High & 20 & 74.1 \\
\hline Total & 27 & 100 \\
\hline
\end{tabular}

The research results indicated that there were only two categories of REBA risk levels suffered by the respondents. Almost all of the respondents (20 people or $74.1 \%$ ) were in the high-level risk. The assessment by implementing the REBA method was gathered from the results of scoring and then determined in the tables of Group A, Group B, and Group C.

Table 4. Respondent Distribution on the Complaints of MSDs in 2016

\begin{tabular}{lcc}
\hline $\begin{array}{l}\text { Complaints of } \\
\text { MSDs }\end{array}$ & $\begin{array}{c}\text { Frequency } \\
(\mathbf{n})\end{array}$ & $\begin{array}{c}\text { Percentage } \\
(\boldsymbol{\%})\end{array}$ \\
\hline Low & 13 & 48.2 \\
High & 14 & 51.8 \\
\hline Total & 27 & 100 \\
\hline
\end{tabular}

According to the results of the NBM questionnaire, 13 respondents (48.1\%) complained about MSDs on the low level with the total individual score of 28-49. Based on the time the complaints, the majority of the respondents stated that the pain was felt during working hours.

Table 5. The Correlation between the Age and the Complaints of MSDs in 2016

\begin{tabular}{ccccccc}
\hline \multirow{2}{*}{$\begin{array}{c}\text { Age } \\
\text { years } \\
\text { old })\end{array}$} & \multicolumn{2}{c}{ Complaint Level of MSDs } & \multicolumn{2}{c}{ Total } \\
\cline { 2 - 5 } & \multicolumn{2}{c}{ Low } & \multicolumn{2}{c}{ High } & & \\
\cline { 2 - 6 } & $\mathbf{n}$ & $\boldsymbol{\%}$ & $\mathbf{N}$ & $\mathbf{\%}$ & $\mathbf{N}$ & $\boldsymbol{\%}$ \\
\hline$<35$ & 7 & 70 & 3 & 30 & 10 & 100 \\
$>35$ & 6 & 35.2 & 11 & 64.8 & 17 & 100 \\
\hline Total & 13 & 48.2 & 14 & 51.8 & 27 & 100 \\
\hline
\end{tabular}


Table 5 revealed that 14 people $(51.8 \%)$ suffered from a high level of MSDs. The group consisted of 3 people (30\%) aged below 35 years old and 11 people $(64.8 \%)$ aged above 35 years old. Based on the cross-tabulation, it was obtained that there was a moderate level of correlation between the workers' ages and the complaints of musculoskeletal disorders felt by the workers in the packaging section.

Table 6. The Correlation between Years of Service and the Complaints of MSDs in 2016

\begin{tabular}{|c|c|c|c|c|c|c|}
\hline \multirow{3}{*}{$\begin{array}{c}\text { Years of } \\
\text { Service }\end{array}$} & \multicolumn{4}{|c|}{ Complaint Level of MSDs } & \multirow{2}{*}{\multicolumn{2}{|c|}{ Total }} \\
\hline & \multicolumn{2}{|c|}{ Low } & \multicolumn{2}{|c|}{ High } & & \\
\hline & $\mathbf{n}$ & $\%$ & $\mathbf{n}$ & $\%$ & $\mathbf{N}$ & $\%$ \\
\hline$<1$ year & 4 & 100 & 0 & 0 & 4 & 100 \\
\hline $1-5$ years & 9 & 39.2 & 14 & 60.8 & 23 & 100 \\
\hline Total & 13 & 48.2 & 14 & 51.8 & 27 & 100 \\
\hline
\end{tabular}

Table 6 confirmed that as many as 14 people $(51.8 \%)$ suffered from a high level of MSDs, which constituted $60.8 \%$ of the workers with the years of service of 1-5 years. The results of the cross-tabulation pointed out that there was a moderate level of correlation between the years of service and the complaints of MSDs of the workers of the packaging section.

Table 7. The Correlation between the Assessment of Working Postures and the Complaints of MSDs in 2016

\begin{tabular}{|c|c|c|c|c|c|c|}
\hline \multirow{3}{*}{$\begin{array}{c}\text { Assessment } \\
\text { of Working } \\
\text { Postures }\end{array}$} & \multicolumn{4}{|c|}{$\begin{array}{c}\text { Complaint Level of } \\
\text { MSDs }\end{array}$} & \multirow{2}{*}{\multicolumn{2}{|c|}{ Total }} \\
\hline & \multicolumn{2}{|c|}{ Low } & \multicolumn{2}{|c|}{ High } & & \\
\hline & $\mathrm{n}$ & $\%$ & $\mathbf{n}$ & $\%$ & $\mathbf{N}$ & $\%$ \\
\hline Low & 1 & 14.3 & 6 & 85.7 & 7 & 100 \\
\hline High & 12 & 60 & 8 & 40 & 20 & 100 \\
\hline Total & 13 & 48.2 & 14 & 51.8 & 27 & 100 \\
\hline
\end{tabular}

Table 7 illustrated that as many as 14 people $(51.8 \%)$ suffered from a high level of MSDs, which consisted of 6 people $(85.7 \%)$ with a low level of working postures and eight people $(40 \%)$ with a high level of working postures. From the results of the cross-tabulation, the phi coefficient reached 0.401 , which indicated that there was a moderate level of correlation between the working postures and the complaints of MSDs felt by the workers of the packaging section.

\section{DISCUSSION}

\section{Individual Characteristics}

The research results suggested that the bigger part of the respondents belonged to the age group of $>35$ years old, amounting to $63 \%$. The age had a strong correlation with the complaints of skeletal muscles, especially on the shoulder and neck muscles. Chaffin, Andersson and Martin (2006) claimed that, generally, the complaints of skeletal muscles began to be felt between the ages of 25-65 years old. The first complaint is felt when entering the age of 35 years old, and the level of complaints increases with age. Other conditions can occur in middle ages, such as the decrease of strength and muscle endurance, causing an increase in the risk of muscle complaints (Tarwaka, 2010)

The research results also demonstrated that most of the respondents' years of service was 1-5 years, amounting to $85.2 \%$. The years of service brings both positive and negative impacts. The positive impact includes the experience the workers have as they have longer years of service. Contrarily, it is known that the longer the years of service is, the more the level of fatigue and boredom will increase. Years of service is the working period calculated since the first day of work until the day this study was conducted. The workers with the years of service of more than five years have a higher risk of suffering from back pain than those with the years of service of less than five years (Boshuizen, Bongers and Hulshof, 1990).

The risk level assessment of MSDs of the working postures during the working hour was carried out by implementing the REBA method. The research on the risk level of MSDs in the production process entailed the straight bar more precisely by using the REBA method. The implementation of the REBA method in determining the risk level assesses not only the 
working postures but also other factors that are likely to increase the risk of MSDs complaints. The assessment was roled as the reference and the working activities performed by the workers.

The scoring assessment by using the REBA method was divided into two groups, i.e., Group A and Group B. The scoring results of Group A and Group B were merged in the score table C. The score table $\mathrm{C}$ was then added with the score of muscle activities types to determine the risk level of working postures.

Group A covered the body, neck, and legs. The individual scores for each group were taken in sequence, based on the table. Table A was used to obtain the initial score of the initial group, including the individual scores of the body, neck, and legs.

Group B covered the upper limbs (upper arms, forearms, and wrists). The scores of Group B were taken from the scores of the upper arms, forearms, and wrists in table B. The modified scores of Group A which based on the force performed was labeled as Score A, while the corrected scores of Group B which based on the container handle was labeled as Score B.

The assessment of the complaint level of MSDs in this study implemented the NBM questionnaire to figure out the parts of the muscles that suffered from the complaints ranging from the level of non-pain to severe pain. The NBM questionnaire covered 27 divisions of skeletal muscles on the right and left sides of the body, from the upper part (neck muscles) to the lower part (legs muscles) of the body. The use of the NBM questionnaire was also to reveal which parts of the muscles that had complaints or pain.

The assessment by applying the NBM questionnaire was carried out by using the YesNo questions. The 'yes' answer indicated that there was a complaint felt in the skeletal muscles. On the other hand, the 'no' answer implied that there was no complaint, no pain felt in the skeletal muscles.

The assessment of the NBM questionnaire was completed by fulfilling the scores of each part of both the right and the left sides of the body, followed by labeling the complaints felt by the respondents with the following scoring: $1=$ not painful; $2=$ mildly painful; $3=$ painful, and 4 $=$ very painful.

The obtained scores were then summed up to attain the final scores of the complaints felt by each respondent. The final scores of the NBM were used to discern the risk level of the complaints felt by each respondent. The final results of the NBM of this study implied that almost all of the workers in the packaging section $(51.8 \%)$ suffered from the high-level of MSDs.

\section{The Correlation between Age and the Complaints of MSDs}

The research results in Table 5 revealed that most of the respondents whose ages were above 35 years old suffered from the high-level of MSDs. The respondents with the ages of below 35 years old suffered from the low-level of the complaints of MSDs.

The results of the cross-tabulation indicated that the older the age, the more increase the complaints of MSDs were experienced by the workers of the packaging section. Tarwaka (2010) and some other experts claimed that the workers with the age of below 35 years old had low risks to suffer from the complaints of MSDs. Generally, the complaints of the skeletal muscles begin to be felt between the ages of 25-65 years old. The first complaint is usually felt when reaching the age of 35 years old, and the level of the complaint will increase with age.

The age is directly proportional to the physical capacity until certain limits. The maximum physical ability occurs at the age of 25 years old. At the age of 50-60 years old, there is a decrease in muscle strength by $25 \%$ and a decrease in sensory-motoric ability by $60 \%$. The physical ability of a person whose age is above 60 years old only reaches $25 \%$ of the working ability of a person whose age is below 60 years old (Tarwaka, Bakri and Sudiajeng, 2004).

Yousefi, Habibi and Tanaka (2016) argued that the highest number of MSDs complaints occurred to the workers with an average age of 36.5 years old. The MSD complaints occurred to 
the workers with an average age of 43.1 years old working on manual works with less ergonomic working postures (Choobineh et al., 2007). The research results are not in line with the results of the study conducted by Rosecrance et al. (2011) who claimed that MSDs also occurred to the workers with the ages of 15-21 years old. This can be caused by the low-level of the ergonomics and the heavy workloads.

\section{The Correlation between the Years of Service and the Complaints of MSDs}

From Table 6, the research results showed that most of the workers who had already worked for 1-5 years suffered from the high-level of MSD complaints. The increase of the years of service tends to be directly proportional to the increase of the occurrence of MSD complaints of the workers in the packaging section.

The increase of the risk complaints of MSDs mostly occurred to the respondents whose years of services were less than five years with the working hours of less than eight hours a day. The research results are contrary to the prior research, which declared that the workers with more than five years of service had higher risks to suffer from lower back pain than the workers whose years of service were less than five years (Ahmad and Budiman, 2014). Yousefi, Habibi and Tanaka (2016) also discovered that the highest level of MSD complaints mostly occurred to the workers with an average of 16.5 years of service ( $>5$ years). It was noticed that the factors that could worsen the complaints of MSDs were the working postures and the individual characteristics, such as age, body mass index, and years of service.

\section{The Correlation between the Working Postures and the Complaints of MSDs}

The complaints of the skeletal muscles are related to body size that can influence the balance of the skeletal structure when receiving some weights (body weights and other additional weights). A tall body has a slender form of bone that is biomechanically susceptible to weight pressures and bending, which makes it has higher risks to suffer from the skeletal muscles complaints (Tarwaka, Bakri and Sudiajeng, 2004).

Tana, Delima and Tuminah (2009) explain that the most influential factors to the complaints of MSDs in the garment industry workers are the years of service and working postures. The workers of the garment industry work in a field with the least risk, because almost all of the works are completed by sitting. However, the working period in a day is also noticed to give a big contribution. The prior research argued that incorrect working postures and shift change system were the main causes of MSDs (Albers et al., 1997); (Chung et al., 2013); (Basahel, 2015).

Tarwaka (2010) claimed that the research results on a pilot group with a high level of body fitness had minor risks of muscle injuries. In other words, the low level of body fitness increased the risk of muscle complaints. The muscle complaints increased along with the increase in physical activities. The study carried out by Nurhikmah (2011) argued that exercises could make the body healthier, providing blood circulation improvement so that the complaints of MSDs could be minimized.

Furthermore, this research results also revealed that the greater part of the respondents did not do daily exercises, because they suffered from a high level of MSD complaints. The results of the cross-tabulation implied that there was a tendency of the improved exercise habit to the increase of the risk of MSDs complaints of the workers in the packaging section. Apparently, this was because the respondents did not do exercises at least every once a week.

Sports activities for joints such as gymnastics or jogging are recommended to be done before work. In addition, to make the body healthier, joint exercises can also strengthen the bond among the workers. Cooper (1994) claims that the intensity of an exercise is sufficient if the pulse reaches $65-80 \%$ of the Maximum Heart Rate (the MHR-age in years).

Moreover, by implementing the REBA method, this research results disclosed that the 
majority of the respondents had the high-risk level of working postures with a low level of MSD complaints. The results of the crosstabulation revealed that the increase of the working postures increased the risk of MSD complaints of the workers in the packaging section.

The REBA method is one instrument to carry out the analysis regarding the sensitive working postures, including a sudden change of a posture because of unexpected handlings (Tarwaka, 2010). The implementation of the REBA method aimed to prevent or minimize the risk level of injuries concerning the body positions, particularly on the skeletal muscles that were likely to happen due to non-ergonomic working postures.

A job with repetitive activities is one of the causes of skeletal muscles complaints. Working postures and body positions are the essential factors that need to be noticed since they affect the final products. The non-ergonomic working postures of the workers can result in several impacts on the workers. Amongst those effects are easy to get tired that decreases the concentration level, slow pace in finishing works, and the end, the decrease of the quality and quantity of the products (Santoso, 2004).

The research results are also in accordance with the previous research that claimed that there was a strong correlation between the working postures and the complaints of musculoskeletal in welding workers due to non-ergonomic working postures (Jalajuwita and Paskarini, 2015; (Choobineh et al., 2007).

\section{CONCLUSION}

Referring to the individual characteristics, this study revealed that $63 \%$ of the respondents aged above 35 years old. In addition, the respondents with the year of services of 1-5 years reached $82.5 \%$.

The REBA analysis results indicated that $74.1 \%$ of the respondents were posed by high-risk level of non-ergonomic working postures. According to the NBM questionnaire, $51.8 \%$ of the respondents suffered from the high-level complaints of MSDs.

Furthermore, there was a moderate correlation between the age, years of services, and working postures and the complaints of MSDs. Additionally, there was a moderate correlation between the working postures and the complaints of MSDs with the phi coefficient of 0.401. In addition, the moderate-correlation level still had impacts on the occurrence of MSD complaints.

\section{ACKNOWLEDGEMENT}

The researcher would like to thank all the respondents for their participation in the research.

\section{REFERENCES}

Ahmad, A. and Budiman, F. (2014) 'The Correlation of Sitting Position with Lower Back Pain in Vermak Levis Tailors in Tanah Pasir Market, Penjaringan, North Jakarta, 2014', Forum Ilmiah, 11(3), pp. 412-420.

Albers, J. T. et al. (1997) 'An Ergonomic Education and Evaluation Program for Apprentice Carpenters', American Journal of Industrial Medicine, 32(6), pp. 641-646.

Basahel, A. M. (2015) 'Investigation of Workrelated Musculoskeletal Disorders (MSDs) in Warehouse Workers in Saudi Arabia', in Procedia Manufacturing. Elsevier B.V., pp. 4643-4649.

Boshuizen, H. C., Bongers, P. M. and Hulshof, C. T. J. (1990) 'Self-reported Back Pain in Tractor Drivers Exposed to Whole-Body Vibration', International Archives of Occupational Evironmental Health, 62(2), pp. 109-115.

Chaffin, D. B., Andersson, G. B. J. and Martin, B. J. (2006) Occupational Biomechanics. 4th edn. New York: John Willey \& Son, Inc.

Choobineh, A. et al. (2007) 'Musculoskeletal Problems Among Workers of an Iranian Rubber Factory', Journal of Occupational and Health, 49(5), pp. 418-423.

Chung, Y.-C. et al. (2013) 'Risk of Musculoskeletal Disorder among 
Taiwanese Nurses Cohort: A Nationwide Population-based study', BMC Musculoskeletal Disorders, 14(144), pp. 16.

Cooper, K. H. (1994) Antioxidant Revolution. Nashville: Thomas Nelson Publisher.

Ide, P. (2007) Inner Healing in The Office. Jakarta: Gramedia.

Jalajuwita, R. N. and Paskarini, I. (2015) 'The Relation between Body Position with Musculoskeletal Complaints in Welding Unit of PT. X Bekasi', The Indonesian Journal of Occupational Safety and Health, 4(1), pp. 33-42.

Notoatmodjo, S. (2005) Health Research Methodology. Jakarta: Rineka Cipta.

Nurhikmah (2011) Factors Associated With Musculoskeletal Disorders (MSDs) in Furniture Workers in the Benda Kota District of Tangerang in 2011. Undergraduate Thesis. Jakarta:Faculty of Medicine and Health Sciences Universitas Islam Negeri Syarif Hidayatullah.

Rosecrance, J. et al. (2011) 'Musculoskeletal Disorders among Construction Apprentices in Hungary', Central European Journal of Public Health, 9(4), pp. 183-187.

Santoso, G. (2004) Ergonomics: Humans, Equipment, and the Environment. Jakarta: Prestasi Pustaka.

Saputra, A. M. T. H., Naiem, F. M. and Saleh, L. M. (2013) 'Factors Related with Musculosceletal Disorders on Hasanuddin University Makassar Financial Department's Computer Operator', Repository Universitas Hasanuddin, pp. 112.

Suma'mur (2009) Corporate Hygiene \& Occupational Health. Jakarta: Sagung Seto.

Tana, L., Delima and Tuminah, S. (2009) 'The Relation between Work Duration and Work Position to Neck and Upper Extremity Musculoskeletal Symptoms among Female Garment Workers in North Jakarta', Bulletin of Health Research, 37(1), pp. 12-22.

Tarwaka (2010) Industrial Ergonomics: Basics of Ergonomics Knowledge and Applications at Work. Solo: Harapan Press Solo.

Tarwaka, Bakri, S. H. A. and Sudiajeng, L.
(2004) Ergonomics for Safety, Occupational Health and Productivity. 1st edn. Surakarta: UNIBA Press.

Woolf, A. D. and Pfleger, B. (2003) 'Burden of Major Musculoskeletal Conditions', Bulletin of the World Health Organization, 81(19), pp. 646-656.

Yousefi, H., Habibi, E. and Tanaka, H. (2016) 'Prevalence of Work Related Musculoskeletal Disorders Among the Iranian Working Population in Different Sectors of Industries', in Goossens, R. H. M. (ed.) International Conference on Social and Occupational Ergonomics. Florida: Walt Disney World. 